\title{
Up-Regulation of S-Phase Kinase Associated Protein-2 Antisense Induces Cell Growth and Migration Chemotactic Suppression and Apoptosis in a Malignant Oral Burkitt's Lymphoma Cells
}

\author{
Supriatno $^{1}$, Sartari Entin Yuletnawati ${ }^{2}$ \\ ${ }^{1}$ Department of Oral Medicine, Faculty of Dentistry, Universitas Gadjah Mada, Yogyakarta, Indonesia \\ ${ }^{2}$ Post-graduate student, Faculty of Dentistry, Universitas Gadjah Mada, Yogyakarta, Indonesia \\ Faculty of Dentistry, Muhamadiyah University, Surakarta, Indonesia
}

\begin{abstract}
Burkitt's lymphoma (BL) is an uncommon type of Non-Hodgkin lymphoma (NHL). It is a highly aggressive type of B-cell lymphoma and the most common childhood cancer. Treatment for this cancer is still limited. However, a new strategy for refractory tumor, gene therapy is watched with keen interest. One of method for high-efficiency and region-controlled in vitro gene transfer was developed by antisense oligonucleotide. In the present study, Skp2 sense ( $45^{\text {Skp2 } 2} S$ ), Skp2 antisense (p45 ${ }^{\text {Skp2 }}$ AS) and Skp2 neo (empty vector) were transfected into an oral Burkitt's lymphoma (Raji) cell line. The aim of study was to examine the Skp2 AS up-regulation toward the cell growth and migration chemotatic suppression and apoptosis induction in an oral Burkitt's lymphoma cells in vitro. The efficiency of Skp2 S and Skp2 AS gene transfection in cell growth inhibition test was confirmed by MTT [3-(4,5-dimethythiazol-2-yl)2,5-diphenyltetrazolium bromide] assay. To estimate the suppression of chemotatic migration cell was examined by Boyden chamber assay and cell growth test. Furthermore, colorimetric assay caspase-3 and caspase-9 were used to know the apoptosis induction. Results revealed the Raji cell growth and migration chemotatic were markedly suppressed by Skp2 AS. Skp2 AS-treated cell induced apoptosis characterized by an increase caspase-3 and -9 proteolytic activities. These results suggest that up-regulated of Skp 2 AS appear to induce cell growth and migration chemotatic suppression and apoptosis induction in Raji cells targeting this molecule could represent a promising new therapeutic approach for this type of tumor.
\end{abstract}

Keyword: cell growth, Skp2 AS, Burkitt's lymphoma cell, apoptosis, migration.

\section{Introduction}

S-phase kinase associated kinase 2 (Skp2), a member of the F-box family, is the substrate-recognition subunit of the $\mathrm{SCF}^{\text {Skp2 }}$ ubiquitin ligase complex. ${ }^{1)}$ Skp2 has been implicated in ubiquitin-mediated degradation of the cyclindependent kinase (CDK) inhibitor $\mathrm{p} 27^{\mathrm{Kip} 1}$, and positively regulates the $G_{1} / S$ transition. ${ }^{2-4)}$ The targeted disruption of Skp2 leads to the accumulation of p27 and cell cycle arrest in $G_{1}$. Moreover, Skp2 has also been required for ubiquitination of other cell-cycle regulators including free cyclin ${ }^{5)}, \mathrm{E} 2 \mathrm{~F} 1^{6}{ }^{6}$ and hOrclp. ${ }^{7)}$ Overexpression of Skp2 has been observed in various type of human tumors. Elevated expression of Skp2 indicates poor prognoses for patients with colorectal, ${ }^{8)}$ lymphoma, ${ }^{9}$ gastric, ${ }^{10)}$ and lung cancers. ${ }^{4)}$ Therefore, Skp2 knock-out mice grow more slowly and have smaller organs than littermate controls, and they show a reduced growth rate and increased apoptosis. ${ }^{5)}$ However, the mechanism of Skp2 overexpression in cancer cells or the nature of its contribution to the malignant phenotype is little known.

Burkitt's lymphoma (BL) is one of the most aggressive malignancies of lymphoid origin and accounts for 3-5\% of all lymphomas. It is a high grade B-cell neoplasm. Usually found in the pediatric population, BL represents $40 \%$ of childhood NHL ${ }^{11)}$. The highest incidence is found in the endemic form in equatorial regions of Africa and PapuaNew Guinea where it accounts for $50-70 \%$ of all pediatric malignancies ${ }^{12)}$. $\mathrm{BL}$ is characterized by chromosome translocations between the proto-oncogene c-myc and one of the immunoglobulin (Ig) loci ${ }^{13)}$. Epstein-Barr virus (EBV) has been implicated in its etiology. BL most often involves the maxilla or the mandible and rarely involves abdominal organs such as kidneys, ovaries or retroperitoneal structures. In the present study, up-regulation of Skp2 AS toward the cell growth and migration chemotatic suppression and apoptosis induction in an oral Burkitt's lymphoma cells in vitro were examined.

\section{Materials and Methods}

Cell and cell culture

Raji cell line (ATCC CCL-86) was obtained from Department of Paracytology, Faculty of Medicine, Universitas Gadjah Mada, Yogyakarta, Indonesia. Cell line was cultured in Dulbecco's modified Eagle medium (Sigmaaldrich, St Louis, MO, USA) supplemented with $10 \%$ fetal calf serum, and $100 \mu \mathrm{g} / \mathrm{ml}$ streptomycin, $100 \mathrm{U} / \mathrm{ml}$ penicillin (Moregate BioTech, Bulimba, Australia). The cultures were incubated in humidified atmosphere of $95 \%$ air and $5 \% \mathrm{CO}_{2}$ at $37^{0} \mathrm{C}$.
Antisense experiments
AS experiments were performed as described previously. ${ }^{14)}$ Two oligonucleotides containing phosphorothioate backbones (Fasmac, Kanagawa, Japan) were synthesized as follows: AS, 5'-TCCTGTGCATAGCGTCCGCAGGCCC- 3' (AS direction of human Skp2 cDNA nucleotides 15 to 25), SC, 5'-CCCGGACGCCTGCGATACGTGTCCT-3' 


\section{International Journal of Science and Research (IJSR) \\ ISSN (Online): 2319-7064}

Index Copernicus Value (2013): 6.14 | Impact Factor (2014): 5.611

(SC for AS). ${ }^{4)}$ The oligonucleotides were delivered into Raji cell line directly according to the manufacturer's instructions.

\section{MTT assay}

Raji cell transfected with AS, S and untreated control (UC) were seeded on 96-well plates (Falcon, NJ, USA) at $1 \times 10^{4}$ cells per well in DMEM containing 10\% FCS, the day before treatment. Cell line was treated with oligonucleotides at final concentration $100 \mu \mathrm{M}$. After 24 hours, the number of cells was quantitated by an assay in which MTT; 3-(4,5dimethylthiazol- 2-yl)-2,5-diphenytetrazolium bromide (Sigma-aldrich) was used. ${ }^{15)}$

\section{Activity of caspase-3 and -9}

Caspase-3 and -9 activities were measured using the colorimetric assay kit according to the manufacturer's directions. This test is based on the addition of a caspasespecific peptide conjugated to a color reporter molecule $\mathrm{p}$ nitroanilide (p-NA). The cleavage of the peptide by caspase releases the chromophore $\mathrm{p}-\mathrm{NA}$, which is quantitated spectrophotometrically at $405 \mathrm{~nm}$. Briefly, equal amounts of cell extracts prepared from Raji cell line transfected with Skp2 AS, S and UC were incubated with the substrate (DVED-pNA and LEHD-pNA; BioVision colorimetric assay kit, CA, USA) in the assay buffer for $2 \mathrm{~h}$ at $37^{\circ} \mathrm{C}$. Absorbance was measured at $405 \mathrm{~nm}$ using a microplate reader (Bio-Rad Laboratories, Hercules, CA, USA). Each determination was conducted in triplicate. ${ }^{14)}$

\section{Chemotactic migration assay}

Chemotaxis (directed migration) was evaluated in the Boyden chamber apparatus (Neuro Probe, Inc., Cabin John, MD, USA). Briefly, subconfluent cells were starved for $24 \mathrm{~h}$ and harvested with $0.05 \% \quad(\mathrm{w} / \mathrm{v})$ trypsin (Invitrogen Corporation, USA) containing $0.02 \%(\mathrm{w} / \mathrm{v})$ ethylenediamine tetra-acetic acid (EDTA, Invitrogen Corporation), washed twice with PBS, and resuspended to a final concentration of $5 \times 10^{5}$ per $\mathrm{ml}$ in serum-free medium with $0.1 \%(\mathrm{w} / \mathrm{v})$ fraction $\mathrm{V}$ bovine serum albumin (BSA, Wako Pure Chemical Industries, Ltd). Polyvinyl-pyrrolidone (PVP) filters (Nuclepore Corp, Palo Alto, CA, USA) of $8-\mu \mathrm{m}$ pore size were precoated with gelatin (Merck KGaA, Frankfurt, Darmstadt, Germany) $(0.1 \mathrm{mg} / \mathrm{ml})$ and rinsed in sterile water. Lower chamber were filled with $30 \mu \mathrm{l}$ of $10 \%$ FBS in DMEM and covered with a gelatin-coated membrane. Furthermore, $50 \mu \mathrm{l}$ of cell suspension, yielding 500 cells $/ \mathrm{ml}$ of Raji-Skp2 AS, Raji-Skp2 S, Raji-UC were added to the upper chamber. After 24 hours of incubation, the membrane was stained with Giemsa solution (Ted Pella Inc., Redding, CA, USA). The number of cells that had penetrated through the filter was counted under light microscope at $400 \mathrm{x}$ magnification. The counting was performed for 12 fields in each concentration.

\section{Statistical analysis}

Statistical differences between the means for the different groups were evaluated with Stat View 4.5 (Abacus Concepts, Berkeley, CA) using one-way ANOVA and $t$-test. The significance level was set at $5 \%$ for each analysis.

\section{Results}

\section{Growth of cells in vitro}

In this examination, the effect of oligonucletides AS, S or $\mathrm{UC}$ at final concentration $100 \mu \mathrm{M}$ on in vitro cell growth of Raji cells was evaluated. ${ }^{16)}$ Relative cell number was evaluated by comparing the absorbance in each cell at 24 hours. The cell number of AS-treated cells was significantly decreased the growth of Raji cells when compared with that of S- and UC-treated cells $(\mathrm{P}=0.015)$ (Figure 1).

\section{Chemotactic migration assay}

Cell migration is an essential process involved in tumor invasion and metastasis. ${ }^{16)}$ The chemotactic ability of each transfection cells with Boyden chamber kit was evaluated for $24 \mathrm{~h}$ incubation. As seen in Figure 2A, Raji-Skp2 AS showed significantly lower ability of chemotactic migration compared with that of the non-treated Raji cells $(\mathrm{P}=0.001)$. Figure 2B indicated Raji-Skp2 AS was markedly inhibited the cell growth when compared with Raji-Skp2 S.

\section{Proteolytic activities of caspase-3 and -9}

The activity of caspase-3 dan -9 in Raji-Skp2 AS, Raji-Skp2 $\mathrm{S}$ and Raji-UC were investigated. Raji-Skp2 AS showed increased caspase-3 and -9 proteolytic activities as compared with that of Skp2 S or UC (Figure 3). Proteolytic activities of caspase-3 in Raji-Skp2 AS was 2.9 fold increased compared with UC. Furthermore, proteolytic activities of caspase-9 in Raji-Skp2 AS was 1.6 fold increased $(\mathrm{P}=$ $0.001)$.

\section{Discussion}

The normal operation of cell cycle requires a delicate balance between positive and negative regulatory factors. Any alteration in this balance can result in abnormal cell proliferation, which may lead to malignant transformation. Loss of normal cell cycle control plays a crucial role in the genesis of most types of cancer. ${ }^{18)}$ S-phase kinase-associated protein 2 was described as an F-box protein constituting the substrate-recognition subunit of the $\mathrm{SCF}^{\mathrm{Skp} 2}$ ubiquitin ligase complex which targets cell-cycle regulator such as the CDK inhibitor p27Kip1, for ubiquitin-mediated degradation. ${ }^{4)} \mathrm{A}$ number of studies have found high levels of Skp2 expression, and its inverse correlation with p27Kip1levels in various types of human tumors have associated with high aggressiveness and poor prognosis. ${ }^{19-20)}$ In the present study, the phosphorotioate oligonucleotide AS strategy was employed to investigate the activity of Skp2 on cell growth and migration chemotactic suppresion and apoptosis induction in a malignant oral Burkitt's lymphoma cell line.

Transfection with AS introduced into cultured Raji cells increased the cell growth and migration chemotactic suppression effect, in contrast to S or UC transfection. These results clearly showed that cell growth and migration chemotactic was inhibited by the AS effect and not by nonspecific effect such as oligonucleotide toxicity. It has been reported that AS oligonucleotides hybridized to the complementary target mRNA and caused a steric or conformational obstacle for protein translation. As a result, the production of a spesific protein is temporarily inhibited without affecting the expression of other genes and without

\section{Volume 4 Issue 12, December 2015}




\section{International Journal of Science and Research (IJSR) \\ ISSN (Online): 2319-7064 \\ Index Copernicus Value (2013): 6.14 | Impact Factor (2014): 5.611}

intervention at the gene level. ${ }^{21)}$ Dias and Stein ${ }^{22)}$ reported that the mechanism of action of AS oligonucleotide can be discerned through the Rnase H-dependent oligonucleotide. These appear to induce the degradation of mRNA and the steric-blocker oligonucleotides, which physically prevent or inhibit the progression of splicing or the translational machinery. Interestingly, oligonucleotide-assisted Rnase Hdependent reduction of targeted RNA expression can be quite efficient, reaching $80-95 \%$ down-regulation of protein and mRNA expression.

As expected from the cell growth and migration chemotactic inhibitory effect, an increase in activation of caspase-3 and 9 in AS-treated cells strongly suggest that apoptosis occured in those cultures. Also, in the current study, increased caspase- 3 and -9 activation in As-treated cells revealed that apoptosis ensued extrinsic and intrinsic pathways. Similar results were reported by Harada et al. ${ }^{22)}$ who suggested that in oral cancer, induction of apoptosis can be caused by down-regulation of Skp2 (or up-regulation of Skp2 AS) .

Several investigators had already reported a relationship between Skp2 and apoptosis in their experiments. S-phase induction by adenovirus-vector mediated expression of Skp2 in quiescent cells was followed by apoptosis. ${ }^{4)}$ Mice embryonic fibroblasts in Skp2-deficient mice showed an increased tendency toward spontaneous apoptosis. ${ }^{5}$ However, the actual role of Skp2 in apoptosis remains unclear. In the present study, Skp2 AS led to apoptosis characterized with induction of caspase- 3 and -9 activities.

In conclusion, up-regulation of Skp2 AS could induce cell growth and migration chemotactic suppression and apoptosis in a malignant oral Burkit's lymphoma (Raji) cell line. In addition, since component of apoptotic programs represent promising targets for anticancer therapy, up-regulation of Skp2 AS approach could be a useful apoptosis-modulating strategy for the treatment of several human cancers.

\section{Acknowledgments}

This research was supported by Unit Jaminan Mutu UGM through Insentif Publikasi Jurnal Internasional grant no. LPPM-UGM/1185/LIT/2014 from Universitas Gadjah Mada, Yogyakarta, Indonesia. The author heartfully thanks and appreciates to Mrs. Rumbi ST, Department of Paracytology, Faculty of Medicine, and to all the staff members at the Department of Oral Medicine, Faculty of Dentistry, Universitas Gadjah Mada, Yogyakarta, Indonesia.

\section{Conflict of interest}

The author wish to express that she has no conflict of interest.

\section{References}

[1] Zhang H, Kobayashi R, Galaktionov K, Beach D. p19Skp1 and p45Skp2 are essential elements of the cyclin A-CDK2 S phase kinase. Cell 1995, 82:915925.

[2] Carrano AC, Eytan E, Hershko A, Pagano M. Skp2 is required for ubiquitin-mediated degradation of the CDK inhibitor p27. Nat Cell Biol 1999, 1:193-199.

[3] Sutterluty H, Chatelain E, Marti A, Wirbelauer C, Senften M, Muller U, et al. p45 (Skp2) promotes p27 (Kip1) degradation and induces $\mathrm{S}$ phase in quiescent cells. Nat Cell Biol 1999, 1:207-214.

[4] Yokoi S, Yasui K, Lizasa T, Takahashi T, Fujisawa T, Inazawa J. Down-regulation of SKP2 induces apoptosis in lung-cancer cells. Cancer Sci 2003, 94:344-349.

[5] Nakayama K, Nagahama H, Minamishima YA, Matsumoto M, Nakamichi I, Kitagawa K, et al. Targeted disruption of Skp2 results in accumulation of cyclin $\mathrm{E}$ and $\mathrm{p} 27^{\mathrm{Kip} 1}$, polyploidy and centrosome overduplication. EMBO J 2000, 19: 2069-2081.

[6] Marti A, Wirbelauer C, Scheffner M, Krek W. Interaction between ubiquitin-protein ligase SCFSkp2 and E2F-1 underlies the regulation of E2F-1 degradation. Nat Cell Biol 1999, 1:14-19.

[7] Mendez J, Zou-Yang XH, Kim SY, Hidaka M, Tansey WP, Stillman B. Human origin recognition complex large subunit is degraded by ubiquitin-mediated proteolysis after initiation of DNA replication. Mol Cell 2002, 9:481-491.

[8] Hershko D, Bornstein G, Ben-Izhak O, Carrano A, Pagano M, Krausz MM, et al. Inverse relation between levels of p27Kip1 and of its ubiquitin ligase subunit Skp2 in colorectal carcinoma. Cancer 2001, 91:17451751.

[9] Chiarle R, Fan Y, Piva R, Boggino H, Skolnik J, Novero $\mathrm{D}$, et al. S-phase kinase-associated protein 2 expression in non-Hodgkin's lymphoma inversely correlates with p27 expression and defines cells in S phase. Am J Pathol 2002, 160:1457-1466.

[10] Masuda TA, Inoue H, Sonoda H, Mine S, Yoshikawa $\mathrm{Y}$, Nakayama $\mathrm{K}$, et al. Clinical and biological significance of S-phase kinase-associated protein 2 (Skp2) gene expression in gastric carcinoma: modulation of malignant phenotype by Skp2 overexpression, possibly via p27 proteolysis. Cancer Res 2002, 62:3819-3825.

[11] Tewfik TL, Bond M, Al-Ghamdi K. Burkitt's lymphoma of the tonsil in children. J Otolaryngol 1996, 25:205-208.

[12] Carbone A, Canzonieri V, GloghiniA, Rinaldo A, Gaidano G, Ferlito A. Burkitt's lymphoma: historical background and recent insights into classification and pathogenesis. Ann. Otol. Rhinol. Laryngol 2000, 109 (7): 693-702.

[13] Salamon D, Adori M, He M, Bonelt P, Severinson E, Kis LL. Type I interferons directly down-regulate BCL-6 in primary and transformed germinal center B cells: Differential regulation in B cell lines derived from endemic or sporadic Burkitt's lymphoma. Cytokine 2012, 57(3):360-71.

[14] Supriatno. S-phase kinase associated protein-2 antisense induces the growth inhibition and apoptosis in a parotid gland cancer cell. HK Dent J 2008, 5:2730.

[15] Supriatno, Harada K, Yoshida H, Sato M. Basic investigation on the development of molecular targeting therapy against cyclin-dependent kinase inhibitor p27Kip1 in head and neck cancer cells. Int J 


\section{International Journal of Science and Research (IJSR) \\ ISSN (Online): 2319-7064 \\ Index Copernicus Value (2013): 6.14 | Impact Factor (2014): 5.611}

Oncol 2005, 27:627-635.

[16] Supriatno, Harada K, Kawaguchi S, Yoshida H, Sato M. Effect of p27Kip1 on the ability of invasion and metastasis of an oral cancer cell line. Oncol Rep 2003, 10:527-532.

[17] Supriatno, Harada K, Kawaguchi S, Onoue T, Yoshida, Sato M. Characteristics of antitumor activity of mutant type $\mathrm{p} 27^{\mathrm{Kip} 1}$ gene in an oral cancer cell line. Oral Oncol 2004, 40: 679-687.

[18] Slingerland J, Pagano M. Regulation of the cdk inhibitor p27 and its deregulation in cancer. J Cell Physiol 2000, 183:10-17.

[19] Esposito V, Baldi A, De Luca A, Groger AM, Loda M,
Giordano GG, et al. Prognostic role of the cyclindependent kinase inhibitor p27 in Non-Small cell lung cancer. Cancer res 1997, 57: 3381-5.

[20] Schlingensiepen R, Brysch W, Schlingensiepen KH. Antisense from technology to therapy, lab manual and textbook. Vol 6, Blackwell Science, Berlin, 1997.

[21] Dias N, Stein CA. Antisense oligonucleotides: Basic concepts and mechanisms. Mol Cancer Ther 2002, $1: 347-355$

[22] Harada K, Supriatno, Kawashima Y, Itashiki Y, Yoshida H, Sato M. Down-regulation of S-phase kinase associated protein $2(\mathrm{Skp} 2)$ induces apoptosis in oral cancer. Oral Oncol 2005, 41:623-630.

\section{Figure Legend}

Figure 1. Relative cell number was evaluated by comparing the absorbance in each cell at 24 hours using MTT assay. Values shown are the mean of six determinations; error bars indicate standard deviations.

Figure 2. A. Analysis of chemotactic migration ability of Skp2 AS, S and UC in Raji cells was examined by Boyden chamber assay. Raji cells treated with Skp2 AS for 24 hours showed significantly lower ability of chemotactic compared with that of the S or UC treated cells. Values are shown as mean; error bars indicate standard deviation. B. The growth of Raji cell transfected with Skp $2 \mathrm{~S}$ and AS for 48 hours.

Figure 3. The activity of caspase-3 and -9 in Raji cell line. Cells were treated with Skp2 AS, Skp2 S or UC oligonucleotides. ** Values are shown as mean; error bars indicate standard deviation.

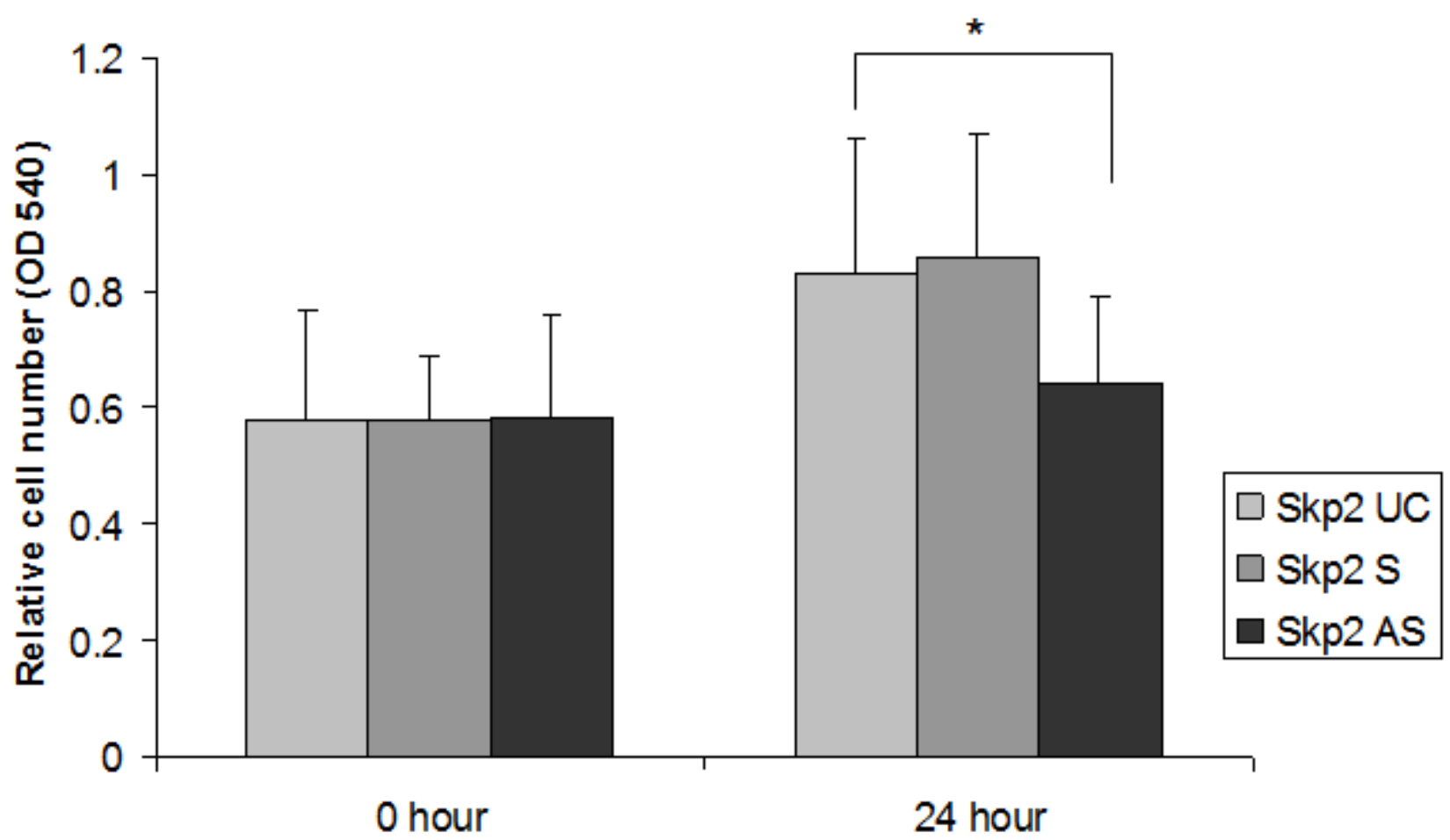

Figure 1 
International Journal of Science and Research (IJSR)

ISSN (Online): 2319-7064

Index Copernicus Value (2013): 6.14 | Impact Factor (2014): 5.611

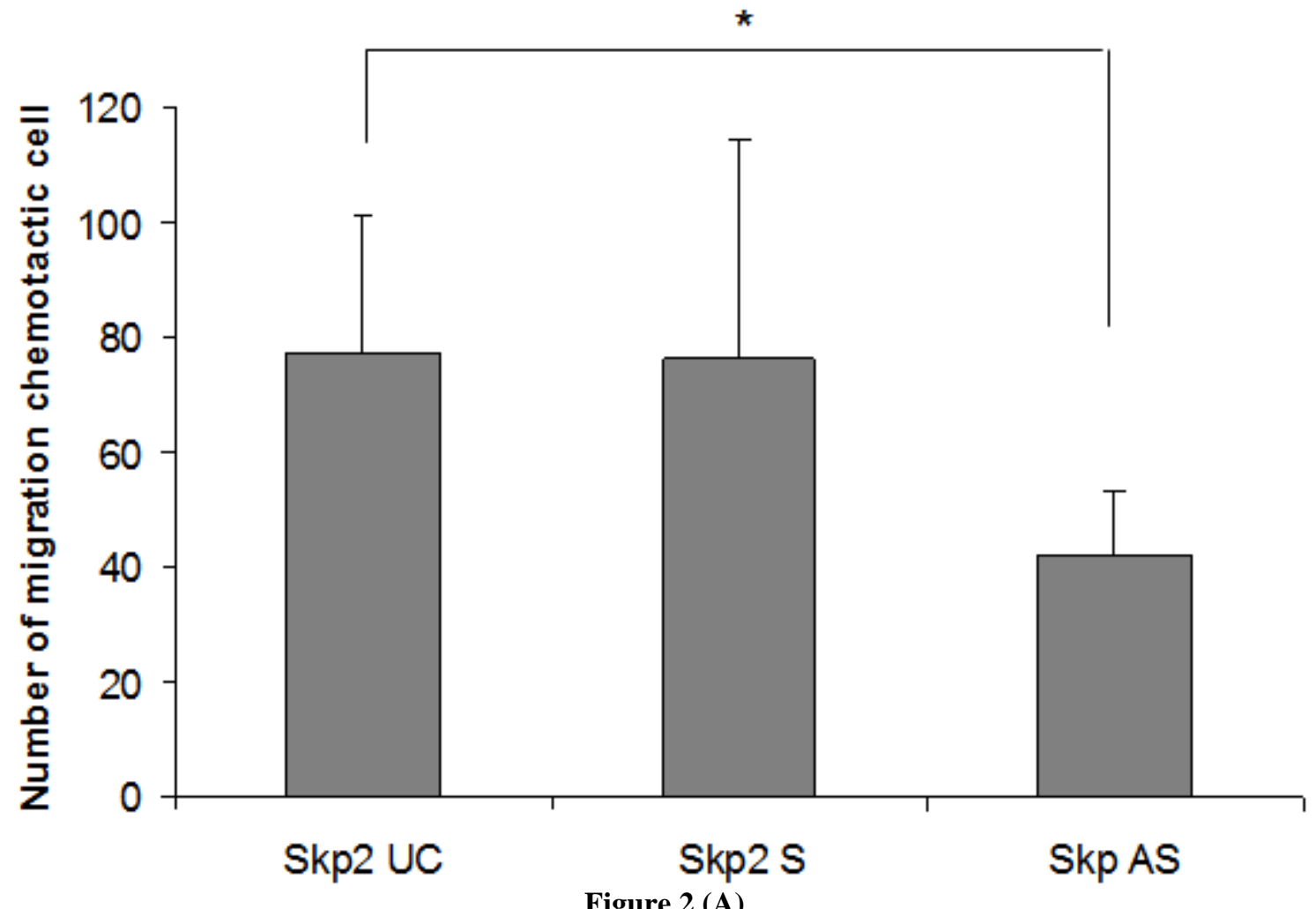

Figure 2 (A)
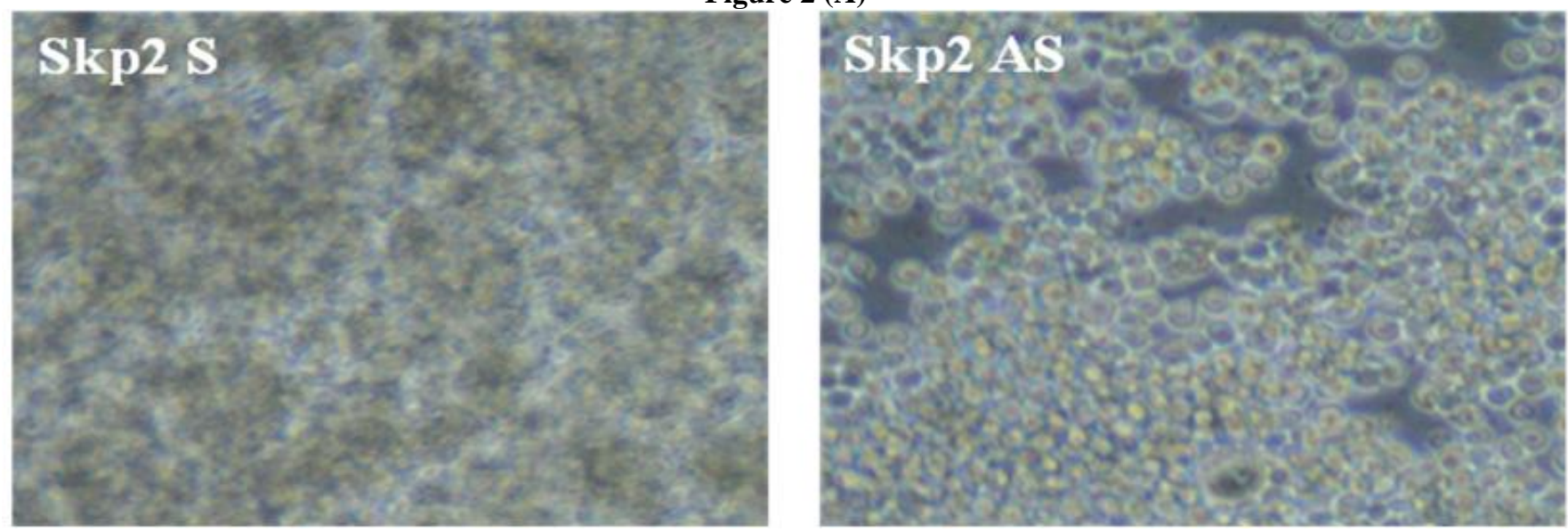

B.

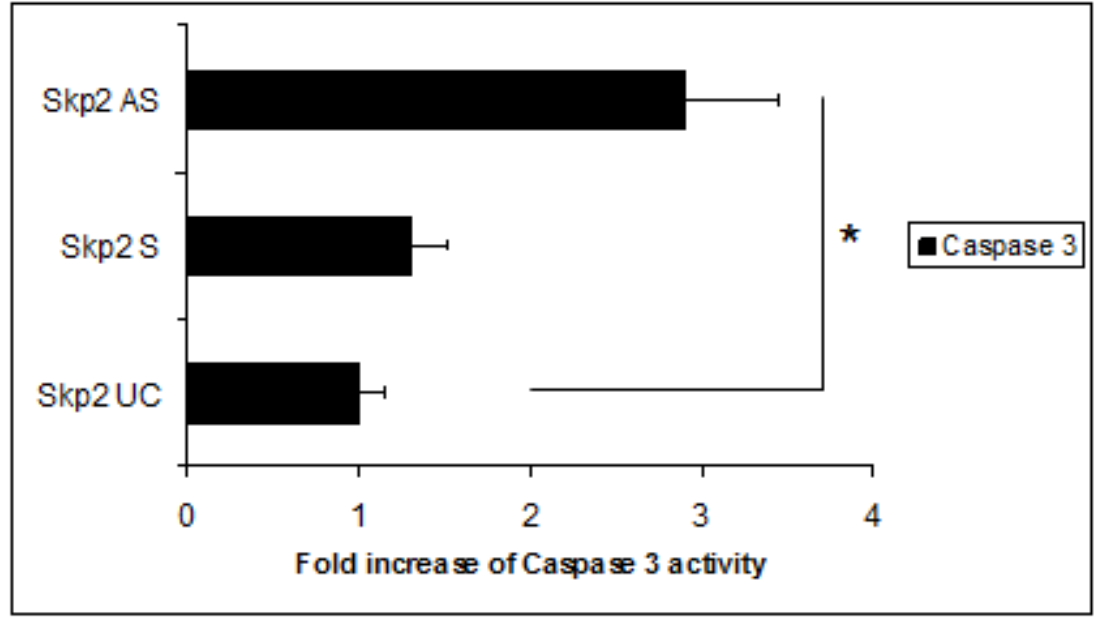

Volume 4 Issue 12, December 2015 www.ijsr.net 
International Journal of Science and Research (IJSR)

ISSN (Online): 2319-7064

Index Copernicus Value (2013): 6.14 | Impact Factor (2014): 5.611

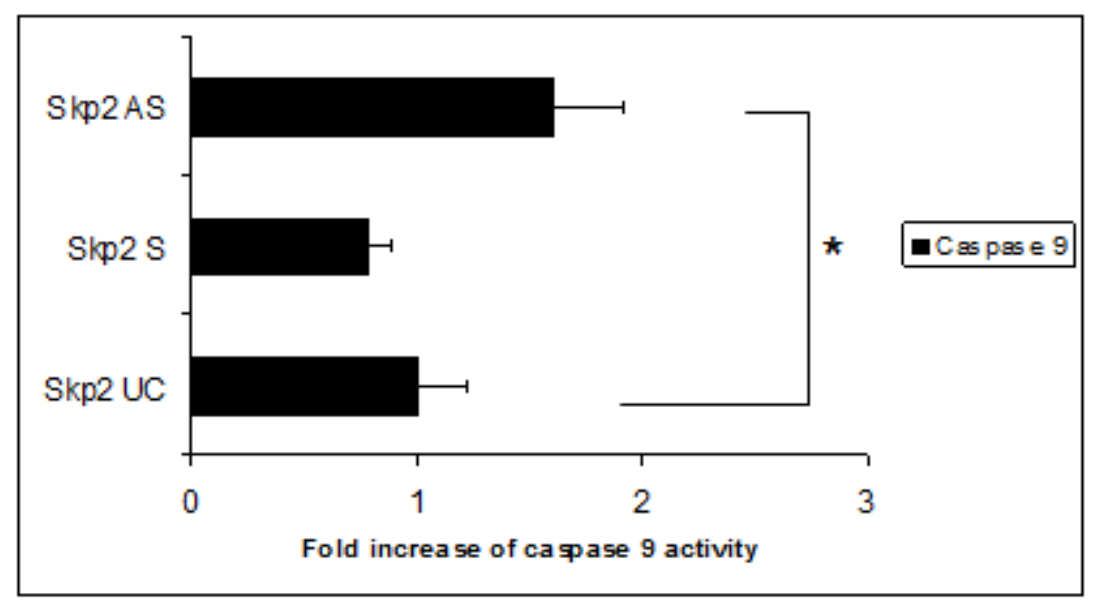

Figure 3

Volume 4 Issue 12, December 2015

www.ijsr.net 